\title{
POLSKA ADAPTACJA NARZĘDZIA DO BADANIA SUBIEKTYWNEJ WITALNOŚCI W UJĘCIU RYANA I FREDERICK
}

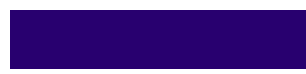

KAROLINA MUDŁO-GŁAGOLSKA *

Uniwersytet Kazimierza Wielkiego w Bydgoszczy, Polska

\section{STRESZCZENIE}

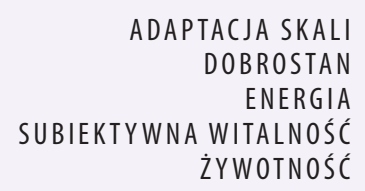

W ostatnich latach zwraca się uwagę na fenomenologiczną jakość witalności. Konstrukt subiektywnej witalności jako marker dobrostanu psychicznego ma tę nad nim przewagę, że jest bardziej dostępny $\mathrm{w}$ doświadczeniu fenomenologicznym, jest niezależny od zewnętrznych kryteriów dobrostanu i różni się od innych konstruktów $\mathrm{z}$ tego obszaru (takich jak np. afekt pozytywny, zaangażowanie w pracę, flow czy satysfakcja z życia). Dotąd możliwość oceny subiektywnej witalności była w Polsce ograniczona, zatem przetestowano trafność i rzetelność polskiej wersji Skali subiektywnej witalności. W próbie 709 osób oceniono trafność czynnikową trzech wersji skali w języku polskim. Na podstawie a Cronbacha i mocy dyskryminacyjnej narzędzie można uznać za rzetelne. Przetestowano trafność skali w aspekcie zbieżnym i różnicowym na podstawie zależności subiektywnej witalności od innych konstruktów psychologicznych. Częściowo potwierdzono wartość predykcyjną satysfakcji z zaspokojenia potrzeb psychologicznych w ogóle i w odniesieniu do pracy. Analiza różnic międzygrupowych wykazała, że wynik subiektywnej witalności u osób chorych i zdrowych somatycznie był istotnie różny. Skale subiektywnej witalności można uznać za narzędzie trafne i rzetelne. Zalecane jest stosowanie jej wersji 5-pozycyjnej. 


\title{
POLISH ADAPTATION OF THE SUBJECTIVE VITALITY SCALE BY RYAN AND FREDERICK
}

\begin{abstract}
In recent years, attention has been paid to the phenomenological quality of vitality. The construct of subjective vitality as a marker of psychological well-being has the advantage over it that it is more accessible in phenomenological experience, is independent of external well-being criteria, such as objective success, health, support or achievements, and goes beyond the semantically known constructs known in Poland, such as affect positive, commitment to work, flow or life satisfaction. Until now, the possibility of assessing subjective vitality was limited, so to fill this gap, the validity and reliability of the Polish version of the Subjective Vitality Scale was tested, which allows the assessment of subjective vitality at the trait level. In a sample of 709 respondents, the factor accuracy of three versions: 7-, 6- and 5-position in Polish was assessed. The 5-position version had the best fit of the model to the data. Analysis of the value of Cronbach's a coefficient and the discriminatory power of the position showed that the scale can be considered reliable. The validity in the convergent and divergent aspect was tested on the basis of the relationship between subjective vitality and the dimensions of chronic fatigue, negative and positive affect, somatic symptoms, anxiety, functional disorders, symptoms of depression, life satisfaction and vitality in a different conceptualization and the number of hours devoted to recreational activities. The predictive value of satisfaction with meeting psychological needs in general and with regard to work was partially confirmed. The analysis of intergroup differences carried out in a sample of 40 people suffering from discopathy and a selected control group showed that the sick and somatically healthy people differed significantly in the result of subjective vitality. The Subjective Vitality Scale can be regarded as an accurate and reliable tool. The 5-item version of the Subjective Vitality Scale is recommended.
\end{abstract}

\section{KEYWORDS}

energy, subjective vitality, scale adaptation, vitality, well-being 


\section{SUBIEKTYWNA WITALNOŚĆ}

ubiektywna witalność (subjective vitality) jest definiowana jako czyjeś świadome doświadczenie posiadania energii i żywotności (Ryan, Frederick, 1997). Teoretyczne korzenie pojęcia witalności sięgają starożytnej filozofii wschodniej (np. chińskiej koncepcji chi, japońskiej koncepcji ki). W myśl jej idei witalność stanowi aktywną siłę wewnętrzną, która sprzyja zdrowiu psychicznemu i fizycznemu. Znaczenie energii wewnętrznej w utrzymywaniu zdrowia podkreślił współcześnie Selye (1956). Uważał on, że ludzie wykorzystują tę energię w obliczu stresorów środowiskowych i chorobowych. Pojęcie witalności sięga także wczesnych teorii psychodynamicznych, traktujących o wolnej od konfliktów energii subiektywnej (np. Freud, 1923, za: Ryan, Frederick, 1997). Teorie te wskazują, że rozwiązywanie konfliktów i integracja wiążą się ze zwiększoną dostępnością energii dla własnego ego. Zgodnie z tym współczesne teorie powiązały subiektywną witalność ze zdrowym funkcjonowaniem i dobrostanem ludzi (Ryan, Deci, 2001).

Wyższy poziom subiektywnej witalności ma osoba wolna od konfliktów, nieograniczana przez zewnętrzne siły oraz przekonana o zdolności do efektywnego działania. Witalność jest konstruktem korespondującym z odczuwaniem siebie jako potencjalnego źródła aktywności (DeCharms, 1968, za: Ryan, Frederick, 1997). Wewnętrznie motywowanym działaniom towarzyszy subiektywna witalność. W rezultacie podejmowane czynności stanowią spontaniczną ekspresję tendencji do asymilowania i integrowania (Ryan, 1995) lub samoaktualizacji (Sheldon, Kasser, 1995). Ryan i Frederick (1997) zakładają, że witalność odnosi się do energii, która jest postrzegana jako wypływająca $z$ wnętrza jednostki i jest wewnętrznie postrzeganym ośrodkiem przyczynowości (Deci, Ryan, 1985).

Subiektywna witalność to stan fenomenologiczny, który jest teoretycznie powiązany z teorią autodeterminacji Ryana i Deciego (2017), opisującą sposób i przyczynę dążenia przez ludzi do dobrego samopoczucia psychicznego i ustanowienia tożsamości zgodnej z ich poczuciem własnego ja. Teoria ta opisuje również, jak warunki społeczne mogą wspierać lub utrudniać ludzki rozwój w zależności od stopnia, w jakim służą jednostkom w zaspokajaniu podstawowych potrzeb psychologicznych z zakresu kompetencji, autonomii i relacji (Ryan, Deci, 2017). Wykazano, że zaspokojenie podstawowych potrzeb psychologicznych jest pozytywnie związane $z$ witalnością, frustracja $z$ powodu podstawowych potrzeb jest natomiast z nią niezwiązana lub związana negatywnie (Ryan, Deci, 2008). Subiektywna witalność nie jest bezpośrednim odzwierciedleniem obserwowalnego wysiłku lub wydatku energetycznego. Jest to związane $\mathrm{z}$ faktem, że energię można wydatkować w zadania, które subiektywnie pochodzą od osoby (wynikające z motywacji wewnętrznej) lub na takie, do których jest się zmuszonym (wynikające $z$ motywacji zewnętrznej). Gdy osoba jest zmotywowana wewnętrznie do angażowania się w zajęcie (w odróżnieniu od zmotywowanej zewnętrznie), jej poziom witalności wzrasta. Wówczas zaangażowanie wynika z potrzeby osoby i jest sposobem wyrażenia siebie.

Subiektywna witalność ma właściwości regenerujące; stanowi siłę, którą jednostki mogą wykorzystać do zmaksymalizowania osobistych zasobów do działania (Deci, Ryan, 2008). Nix, Ryan, Manly i Deci (1999) podkreślili, że wspomniana zdolność regeneracyjna jest specyficzna wyłącznie dla subiektywnej witalności. Ludzie, którzy odczuwają wysoki poziom witalności, mają tendencję do pozytywnego postrzegania wydarzeń i takich też oczekują (Arkes, Herren, Isen, 1988). Subiektywna witalność jest niezależna od zewnętrznych kryteriów dobrostanu, takich jak obiektywny sukces, zdrowie, wsparcie czy osiągnięcia (Ryan, Frederick, 1997).

Wyniki badań potwierdziły funkcję adaptacyjną subiektywnej witalności (Ryan, Deci, 2008). Subiektywna witalność jest silnie związana zarówno z behawioralnymi, jak i obiektywnymi wynikami zdrowotnymi. Została powiązana ze specyficznymi konfiguracjami aktywacji mózgu i mechanizmami pozytywnej odpowiedzi (Rizzolatti, Sinigaglia, 2016; 
Rozanski, Blumenthal, Davidson, Saab, Kubzansky, 2005). Osoby witalne lepiej sobie radzą ze stresem i wyzwaniami oraz zgłaszają lepsze zdrowie psychiczne (Ryan, Frederick, 1997), są bardziej odporne na stresory i mniej podatne na choroby niż osoby o niższym poziomie witalności (Benyamini, Idler, Leventhal, Leventhal, 2000; Cohen, Alper, Doyle, Treanor, Turner, 2006; Polk, Cohen, Doyle, Skoner, Kirschbaum, 2005). Badania te nie wykazały różnic między płciami w subiektywnej witalności.

Podobnie jak w przypadku pozytywnego i braku negatywnego afektu, subiektywna witalność jest uważana za ważny aspekt subiektywnego samopoczucia (Ryan, Deci, 2001). Zgodnie z tym poglądem stwierdzono, że subiektywna witalność jest istotnie związana z wyższym afektem pozytywnym i niższym afektem negatywnym (Martela, Ryan, 2016; Ryan, Frederick, 1997). Jak zauważyli Martela, DeHaan i Ryan (2016), pozytywny afekt obejmuje wymiary o wysokiej aktywacji (np. uczucie aktywności, energii lub wigoru), jak również wymiary o niskiej aktywacji (np. odczuwanie zadowolenia). W przeciwieństwie do niego subiektywna witalność jest bardziej specyficzna i obejmuje tylko wymiary o wysokiej aktywacji.

Depresja, niepokój, objawy somatyczne czy zmęczenie to pojęcia kontrastujące z definicją subiektywnej witalności. Lęk wiąże się z uczuciem napięcia i niekontrolowanego zmartwienia, $\mathrm{z}$ kolei depresja jest związana przede wszystkim z utratą zainteresowania i obniżonym nastrojem, co ma negatywny wpływ na subiektywną witalność. Zmęczenie wskazuje na utratę energii, podczas gdy subiektywna witalność wskazuje na dostęp do energii. Ryan i Frederick (1997) stwierdzili niższe poziomy subiektywnej witalności u pacjentów z bólem w porównaniu z dobraną grupą kontrolną osób zdrowych. Wyniki te zostały potwierdzone przez Goldbecka, Hautzingera i Wolkenstein (2019).

Subiektywna witalność stanowi jeden $\mathrm{z}$ aspektów dobrego samopoczucia, jest związana z zadowoleniem z życia. Dowiodły tego badania Goldbecka i in. (2019), Salamy-Younesa (2011) czy Uysala, Saticiego, Satici i Akina (2014), wskazując na wysoką bądź przeciętną zależność między tymi zmiennymi. Ludzie odczuwają większą witalność, kiedy mają mniej negatywny nastrój i kiedy mają bardziej pozytywny nastrój. Ryan i Frederick (1997) wykazali przeciętną zależność pozytywną między afektem pozytywnym a subiektywną witalnością.

Subiektywna witalność została również powiązana ze wskaźnikami behawioralnymi. Ryan, Bernstein i Brown (2010) wykazali podwyższony poziom subiektywnej witalności podczas weekendu w porównaniu z normalnymi dniami pracy. Autorzy wyjaśniają to wzrostem możliwości zaspokojenia potrzeb w trakcie samodzielnego spędzania czasu wolnego. Zależność ta została potwierdzona w badaniach Goldbecka i in. (2019).

Pojęcie subiektywnej witalności wykracza znaczeniowo poza dotychczas poznane w Polsce konstrukty, takie jak afekt pozytywny, zaangażowanie w pracę, flow czy satysfakcja z życia (Huta, Waterman, 2014). Podczas gdy konstrukty takie jak szczęście czy satysfakcja z życia dotyczą poznawczej oceny własnego życia, subiektywna witalność jest zmienną bardziej emocjonalną, uwarunkowaną biologicznie (Ryan, Frederick, 1997).

\section{SKALA SUBIEKTYWNEJ WITALNOŚCI}

Pozycje Skali subiektywnej witalności, zaproponowanej przez Ryana i Frederick (1997), odnoszą się do postrzegania posiadania energii, zapału, zainteresowań, celów życiowych i poczucia żywotności. Skala składa się z siedmiu pozycji wchodzących w skład jednego czynnika - subiektywnej witalności. W wyniku modelowania równań struktur Bostic, $\mathrm{Ru}^{-}$ bio i Hood (2000) zasugerowali, że dopasowanie modelu można poprawić, usuwając jedyną pozycję odwróconą (pozycja druga). Z kolei Kawabata, Yamazaki, Guo i Chatzisarantis 
(2017) potwierdzili trafność czynnikową skali składającej się z pięciu pozycji (dodatkowo wykluczono pozycję piątą).

Kawabata i in. (2017) zalecili stosowanie wersji 5-itemowej (tabela 2) ze względu na to, że pozycje druga i piąta skali 7-pozycyjnej byly problematyczne $z$ metodologicznego i merytorycznego punktu widzenia. Zgodnie z badaniem Bostica i in. (2000) pozycja druga nie była silnym wskaźnikiem subiektywnej witalności zarówno dla próbek japońskich, jak i singapurskich. Jej słabe ładowanie było związane z faktem, że to pozycja odwrócona (por. Wang, Chen, Jin, 2015). Dopasowanie modeli 6- i 5-pozycyjnych do danych było porównywalne lub lepsze niż dopasowanie modelu 7-pozycyjnego. Wartości kryterium informacyjnego Akaikego (AIC) wskazywały konsekwentnie dla obu próbek, że model składający się z pięciu pozycji był modelem dopasowanym najlepiej (Kawabata i in., 2017). Informacje te skłoniły badaczy do rekomendowania wykorzystywania 5-pozycyjnej Skali subiektywnej witalności (Kawabata i in., 2017). Wersja składająca się z pięciu pozycji jest też regularnie stosowana przez pierwszego autora oryginalnej skali (Bertrams, Dyllick, Englert, Krispenz, 2020).

Skala subiektywnej witalności została zastosowana w badaniach różnych prób, w tym wśród populacji ogólnej (Gunnell, Crocker, Mack, Wilson, Zumbo, 2014), studentów (Reis, Sheldon, Gable, Roscoe, Ryan, 2000; Sheldon, Ryan, Reis, 1996), pacjentów z różnymi schorzeniami (Dawes i in., 2014; Gumz i in., 2015; Kenyon i in., 2015; Rouse i in., 2015), kadetów wojskowych (L. A. S. Souza, Torres, Barbosa, Lima, L. E. C. Souza, 2015) czy sportowców (Adie, Duda, Ntoumanis, 2012).

Skala ta została zaadaptowana na kilkanaście języków, w tym: francuski, grecki, perski, arabski, chorwacki, portugalski, hiszpański, rosyjski, koreański, japoński i niemiecki. Badania te potwierdziły jednoczynnikową strukturę Skali subiektywnej witalności oraz jej rzetelność.

\section{CEL BADAŃ I HIPOTEZY}

Celem niniejszych badań było opracowanie polskiej wersji językowej Skali subiektywnej witalności, oceniającej witalność na poziomie cechy, i oszacowanie rzetelności i trafności skali. Postawiono następujące hipotezy badawcze:

H1: Struktura Skali subiektywnej witalności jest jednoczynnikowa.

H2: Istnieje negatywny związek między subiektywną witalnością a zmęczeniem przewlekłym (podskalami: subiektywnego odczucia zmęczenia, pogorszenia koncentracji uwagi, obniżenia motywacji, zmniejszenia aktywności), symptomami somatycznymi, niepokojem, zaburzeniami funkcjonowania i symptomami depresji, afektem negatywnym.

H3: Istnieje pozytywny związek między subiektywną witalnością a witalnością (w innej operacjonalizacji), satysfakcją z życia, afektem pozytywnym.

H4: Istnieje pozytywny związek między subiektywną witalnością a liczbą godzin spędzonych na aktywnościach rekreacyjnych.

H5: Zaspokojenie potrzeb autonomii, kompetencji i relacji w pracy jest pozytywnym predyktorem subiektywnej witalności.

H6: Zaspokojenie potrzeb autonomii, kompetencji i relacji w ogóle jest pozytywnym predyktorem subiektywnej witalności.

H7: Osoby zdrowe mają istotnie wyższy wynik subiektywnej witalności niż osoby $\mathrm{z}$ dyskopatią. 


\section{METODA}

\section{PROCEDURA ADAPTACJI I WALIDACJ}

Pierwszy etap adaptacji stanowiło przetłumaczenie skali, a następnie sprawdzenie jej równoważności językowej (badanie 1). Trafność teoretyczna została ustalona w drodze szeregu procedur. Trafność teoretyczną skali zweryfikowano za pomocą analizy głównych składowych oraz konfirmacyjnej analizy czynnikowej (CFA; badanie 2). Rzetelność metody oszacowano na podstawie współczynników alfa Cronbacha (badanie 2) oraz mocy dyskryminacyjnej pozycji - współczynników korelacji twierdzeń z wynikiem ogólnym (badanie 2). Trafność teoretyczna została przetestowana na podstawie zależności subiektywnej witalności od innych konstruktów psychologicznych (aspekt zbieżny i różnicowy; badania 3-6), od zewnętrznego korelatu (badania 5,6 ) i podstawowych potrzeb psychologicznych w ogóle (badanie 5) oraz w odniesieniu do pracy (badanie 3). Dodatkowo porównano średnie wyniki w skali uzyskane w grupie osób zdrowych oraz wyniki osób cierpiących na dyskopatię (analiza różnic międzygrupowych; badanie 7).

\section{ADAPTACJA JĘZYKOWA SKALI SUBIEKTYWNEJ WITALNOŚCI}

Zgodnie z przyjętymi standardami oryginalną wersję skali przetłumaczyło na język polski dwóch niezależnych tłumaczy zawodowych. Wersje te nie różniły się znacznie. Największą rozbieżność zaobserwowano w przypadku pozycji 2 . W dosłownym przekładzie, zaproponowanym przez jednego z tłumaczy, otrzymano stwierdzenie „Nie czuję się bardzo energiczny”. Jednak zdecydowano się na tłumaczenie najkrótsze, w którym pominięto partykułę „nie”, zastosowaną w wersji oryginalnej, i otrzymano tym sposobem stwierdzenie „Brak mi energii”. Następnie zastosowano procedurę tłumaczenia zwrotnego na język angielski. Znaczną różnicę zaobserwowano znów w przypadku przywołanej pozycji drugiej. Jednak mimo to przystano na wykorzystanie krótszej wersji pozycji.

\section{CHARAKTERYSTYKA BADANYCH GRUP}

Badania walidacyjne przeprowadzono w siedmiu próbach. W tabeli 1 wskazano liczbę osób biorących udział w badaniach wraz z ogólną charakterystyką demograficzną oraz wskazaniem celu badania konkretnych prób. Pierwszą próbę $(N=28)$ stanowili studenci filologii angielskiej w wieku 22 lub 23 lata. Drugą próbę $(N=709)$ stanowily osoby w wieku od 18 do 67 lat, w tym pracujący studenci studiów niestacjonarnych oraz osoby zatrudnione w różnych sektorach (szczególnie zawody społeczne i urzędnicze) ze stażem pracy od dwóch miesięcy do 47 lat, głównie $\mathrm{z}$ wykształceniem wyższym $(44,43 \%)$ bądź średnim $(22,43 \%)$. Trzecią próbę $(N=250)$ reprezentowali pracownicy głównie zawodów technicznych w wieku od 23 do 66 lat ze stażem pracy od pięciu do 46 lat. Czwartą próbę stanowiły osoby na emeryturze, w wieku od 64 do 75 lat. Kolejna, piąta próba to studenci stacjonarnych studiów pedagogicznych i informatycznych w wieku od 19 do 25 lat. Próbę szóstą reprezentowali sportowcy - amatorzy, szczególnie kolarze i biegacze, w wieku od 20 do 47 lat. Ostatnia, siódma próba to osoby ze zdiagnozowaną dyskopatią, w wieku od 26 do 50 lat, 
borykające się z chorobą od niespełna sześciu lat $(M=5,67 ; S D=2,44)$. Każda z badanych osób podejmuje leczenie lub rehabilitację związaną z chorobą.

\section{PROCEDURA BADAŃ}

Badania walidacyjne były prowadzone od stycznia 2019 roku do lipca 2020 roku. Uczestnicy badania zostali poproszeni o wypełnienie kwestionariuszy $\mathrm{w}$ trakcie spotkania $\mathrm{z}$ badaczem przy użyciu papieru i ołówka albo przez internet $\mathrm{z}$ wykorzystaniem formularza Google. Wszyscy uczestnicy zostali poinformowani o celu badania, o tym, że ich udział jest dobrowolny, a ich odpowiedzi będą anonimowe. Badanie osób z próby 1 odbyło się metodą papier-ołówek, badania w pozostałych próbach zostały przeprowadzone online. W przypadku badania 1 studenci pierwszego roku studiów magisterskich na kierunku filologia angielska wypełniali skalę dwukrotnie - najpierw wersję angielską, a po miesiącu wersję polską. W badaniach internetowych link $\mathrm{z}$ formularzem był umieszczany na portalu spolecznościowym, w grupach skupiających grupy docelowe, np. sportowców, osoby aktywne zawodowe, emerytów, borykające się z dyskopatią.

Tabela 1. Liczebność, wiek, płeć, podstawowa charakterystyka i cel badania poszczególnych grup badanych

\begin{tabular}{|c|c|c|c|c|c|}
\hline \multirow{2}{*}{ Badanie / próba } & \multirow{2}{*}{$\begin{array}{c}N \\
\text { (\% kobiet) }\end{array}$} & \multirow{2}{*}{ Główne zajęcie } & \multicolumn{2}{|c|}{ Wiek } & \multirow{2}{*}{ Cel badania } \\
\hline & & & $M$ & SD & \\
\hline 1 & $28(67,86)$ & Studenci filologii angielskiej & 22,12 & 1,05 & Ocena równoważności językowej \\
\hline 2 & $709(61,72)$ & $\begin{array}{l}\text { Różna charakterystyka } \\
\text { socjodemograficzna }\end{array}$ & 36,54 & 13,48 & $\begin{array}{l}\text { Ocena struktury skali, ocena spójności } \\
\text { wewnętrznej }\end{array}$ \\
\hline 3 & $250(63,20)$ & Pracownicy & 35,44 & 14,52 & $\begin{array}{l}\text { Ocena trafności w aspekcie zbieżnym } \\
\text { i różnicowym }\end{array}$ \\
\hline 4 & $89(83,15)$ & Emeryci & 67,25 & 5,65 & $\begin{array}{l}\text { Ocena trafności w aspekcie zbieżnym } \\
\text { i różnicowym }\end{array}$ \\
\hline 5 & $91(61,54)$ & Studenci & 21,11 & 3,14 & $\begin{array}{l}\text { Ocena trafności w aspekcie zbieżnym } \\
\text { i różnicowym }\end{array}$ \\
\hline 6 & $244(57,79)$ & Sportowcy & 31,52 & 8,75 & $\begin{array}{l}\text { Ocena trafności w aspekcie zbieżnym } \\
\text { i różnicowym }\end{array}$ \\
\hline 7 & $80(97,50)$ & $\begin{array}{l}\text { Osoby z dyskopatią i dobrana } \\
\text { grupa kontrolna }\end{array}$ & 34,66 & 9,96 & Analiza różnic międzygrupowych \\
\hline
\end{tabular}

\section{NARZĘDZIA BADAWCZE}

Choć procedura adaptacji w znacznej mierze odpowiadała zaproponowanej przez Goldbecka i in. (2019), w przypadku narzędzi badawczych trudno było o ich ścisłą odpowiedniość ze względu na brak polskich adaptacji większości narzędzi zastosowanych przez badaczy. Wobec tego starano się badać innymi narzędziami jak najbardziej zbliżone teoretycznie konstrukty.

Osoby biorące udział w badaniu wypełniały kwestionariusz będący polskim tłumaczeniem pełnej wersji oryginalnej Skali subiektywnej witalności. Oryginalna wersja skali składa się z siedmiu pozycji (tabela 2). Wersja 6-elementowa zawiera pozycje 1, 3, 4, 5, 6 i 7 (Bostic i in., 2000), wersja 5-elementowa obejmuje pozycje 1, 3, 4, 6 i 7 (Kawabata i in., 2017). 
Pozycje należy oceniać w 7-punktowej skali Likerta. W badaniu poproszono uczestników o wskazanie, w jakim stopniu dane stwierdzenie odnosi się ogólnie do życia osoby badanej.

Tabela 2. Pozycje oryginalnej Skali subiektywnej witalności i jej polskie tłumaczenia

\begin{tabular}{cll}
\hline Pozycja & \multicolumn{1}{c}{ Wersja oryginalna } & \multicolumn{1}{c}{ Wersja polska } \\
\hline 1 & Ifeel alive and vital. & Czuję się pełny życia i wigoru. \\
\hline 2 & I don't feel very energetic. & Brak mi energii. \\
\hline 3 & Sometimes / am so alive l just want to burst. & $\begin{array}{l}\text { Czasami czuję się tak pełny energii, jakbym } \\
\text { miał wybuchnąć. }\end{array}$ \\
\hline 4 & I have energy and spirit. & Mam energię i zapał. \\
\hline 6 & Ilook forward to each new day. & $\begin{array}{l}\text { Z niecierpliwością czekam na każdy nowy } \\
\text { dzień. }\end{array}$ \\
\hline 7 & I nearly always feel awake and alert. & Niemal zawsze jestem czujny i w gotowości. \\
\hline
\end{tabular}

Adnotacja. Wersja 6-pozycyjna: pozycje 1, 3, 4, 5, 6 i 7 (Bostic i in., 2000); wersja 5-pozycyjna: pozycje 1, 3, 4, 6 i 7 (Kawabata i in., 2017).

Do oceny symptomów somatycznych, niepokoju, zaburzeń funkcjonowania i symptomów depresji wykorzystano Kwestionariusz ogólnego stanu zdrowia (GHQ-28) Goldberga, w adaptacji Makowskiej i Merecz (2001). Narzędzie to służy do oceny stanu zdrowia psychicznego dorosłych, pozwalając na przesiewowe wyłonienie osób z ryzykiem zaburzeń zdrowia psychicznego, przy czym im wyższy wynik, tym większe nasilenie doświadczanych trudności (Makowska, Merecz, 2001).

Kwestionariusz subiektywnej oceny samopoczucia w polskiej adaptacji Makowiec-Dąbrowskiej i Koszady-Włodarczyk (2006) wykorzystano do oceny poziomu zmęczenia przewlekłego. Poziom zmęczenia ocenia się w czterech obszarach: (1) subiektywnego odczucia zmęczenia, (2) pogorszenia koncentracji uwagi, (3) obniżenia motywacji, (4) zmniejszenia aktywności. Badani wskazywali na 7-stopniowej skali, w jakim stopniu każde ze stwierdzeń odpowiada ich odczuciom w okresie dwóch tygodni poprzedzających badanie (Makowiec-Dąbrowska, Koszada-Włodarczyk, 2006).

Do pomiaru satysfakcji z życia posłużyła Skala satysfakcji z życia w polskiej adaptacji Juczyńskiego (2001). Skala zawiera pięć stwierdzeń. Badany ocenia, w jakim stopniu każde $\mathrm{z}$ nich odnosi się do jego dotychczasowego życia. Odpowiedzi udzielane są na skali 7-stopniowej. Wynik ogólny to suma wszystkich ocen; stanowi zarazem wskaźnik poczucia zadowolenia z życia.

Skala uczuć pozytywnych i negatywnych w polskiej adaptacji Brzozowskiego, Watsona i Clark (2010) posłużyła do pomiaru nasilenia negatywnych i pozytywnych emocji. Skala ma postać listy 30 przymiotników. Badany ocenia w skali od 1 do 5 stopień, w jakim przymiotniki określają to, jak czuje się zazwyczaj. Wyniki skali oblicza się osobno dla podskal uczuć pozytywnych (PU) i negatywnych (NU).

W badaniu wykorzystano podskalę witalności Kwestionariusz oceny jakości życia SF-36 w polskiej adaptacji Tylki i Piotrowicza (2009). Kwestionariusz SF-36 jest narzędziem do ogólnej oceny jakości życia zależnej od zdrowia. Za pomocą podskali witalności dokonuje 
się pomiaru poczucia energii, zmęczenia i wyczerpania. $\mathrm{Na}$ tę podskalę składają się cztery pytania, na które w odpowiedzi wskazuje się, ile razy w ciągu ostatniego miesiąca wystąpił dany objaw. Stwierdzenia oceniane są według skali 6-stopniowej (0-5 punktów), gdzie najwyższa wartość punktowa oznacza najwyższy stopień w ocenie witalności, a najniższa wartość - poziom najniższy. Jako zewnętrzny korelat do walidacji skali wykorzystano średnią liczbę godzin spędzanych tygodniowo na zajęciach rekreacyjnych (Goldbeck i in., 2019).

Zaspokojenie podstawowych potrzeb psychologicznych oceniono, odwołując się zarówno do życia ogólnie, jak i ściśle do pracy. Wykorzystano Skale podstawowych potrzeb psychologicznych - ogólną oraz odnoszącą się do pracy (Deci, Ryan, 2000; Gagné, 2003). Każdą z tych skal tworzy 21 pozycji, będących składowymi trzech wymiarów: potrzeby autonomii, kompetencji oraz relacji. Odpowiedzi udziela się na 7-stopniowej skali Likerta. W wypadku skali ogólnej wykorzystano tłumaczenie zaproponowane przez Uchnasta w 2007 roku. Skale podstawowych potrzeb psychologicznych w pracy przetłumaczyła natomiast autorka niniejszego artykułu. Ta wersja tłumaczenia została z powodzeniem wykorzystana w innej pracy, w której każda z podskal i wynik globalny uzyskały zadowalające wskaźniki rzetelności (alfa dla wyniku ogólnego = 0,89).

\section{ANALIZA STATYSTYCZNA}

Kolejne kroki przeprowadzone w analizie statystycznej są w znacznej części analogiczne do tych zaproponowanych przez Goldbecka i in. (2019). Przeprowadzono analizę głównych składowych w celu określenia struktury Skali subiektywnej witalności w polskiej próbie. Następnie przeprowadzono konfirmacyjną analizę czynnikową (CFA) w celu oceny dopasowania modelu do danych. Przetestowano skalę składającą się z 5, 6 oraz 7 pozycji. Wykorzystano estymator największej wiarygodności (MLM; maximum likelihood mean adjusted), który jest odporny na odchylenia od wielowymiarowego rozkładu normalnego. Ze względu na wartość współczynnika kurtozy wielowymiarowej $(13,19)$ zdecydowano się dodatkowo sprawdzić dopasowanie modelu $\mathrm{z}$ wykorzystaniem innego estymatora - diagonalnie ważonych kwadratów (DWLS; diagonally weighted least squares). Ocenę dopasowania przeprowadzono w oparciu o następujące miary: $\chi^{2} / d f$, porównawczy indeks dopasowania (CFI), indeks Tuckera-Lewisa (TLI), pierwiastek średniokwadratowego błędu aproksymacji (RMSEA), wystandaryzowany pierwiastek średniego kwadratu reszt (SRMR) i AIC. Nieistotny wynik testu $\chi^{2}$ wskazuje, że testowany model teoretyczny nie różni się istotnie od uzyskanych danych empirycznych. Dla akceptowalnego dopasowania modelu CFI i TLI powinny wynosić 0,90 lub więcej (Kline, 2005). Wskaźniki RMSEA oraz SRMR powinny natomiast wynosić 0,08 lub mniej, a $90 \%$ przedział ufności nie powinien przekraczać 0,10 dla akceptowalnego dopasowania modelu (Kline, 2005). W oparciu o wyniki CFA i bazując na wcześniejszych pracach (Goldbeck i in., 2019; Kawabata i in., 2017), do dalszej analizy wykorzystano wersję 5-pozycyjną (Załącznik 1).

Zgodnie z podejściem zaproponowanym przez Goldbecka i in. (2019), zanim oceniono trafność diagnostyczną, przeprowadzono regresję wielokrotną w celu przetestowania związku wieku, płci i statusu studenta z subiektywną witalnością. Ogólny model nie osiągnął istotności $(F[5,703]=0,49 ; p=0,083)$. Stąd ani wiek, płeć czy status studenta, ani ich interakcje nie były istotnie związane $\mathrm{z}$ subiektywną witalnością.

Analizy korelacji i regresji wielorakiej zostały wykorzystane także do oceny trafności teoretycznej Skali subiektywnej witalności. Trafność teoretyczną określono również na podstawie wyników testu $t$ Studenta dla prób niezależnych w próbach osób chorych na dyskopatię i dobranej grupy kontrolnej (analiza różnic międzygrupowych). Do analizy wykorzystano programy Statistica 13.3 i R 3.6.1 wraz z pakietem lavaan. 


\section{WYNIKI}

\section{BADANIE 1: ANALIZA RÓWNOWAŻNOŚCI JĘZYKOWEJ}

W analizie posłużono się współczynnikiem korelacji wewnątrzklasowej (Akaike, 1987). Wartość zależności między wersjami testu wyniosła 0,82 . Z kolei między pozycjami wartości przyjmowały zakres od 0,80 do 0,87 , co świadczy o wysokiej zależności między wersjami testu i wysokiej zgodności językowej narzędzia.

\section{BADANIE 2: CHARAKTERYSTYKA PSYCHOMETRYCZNA I STRUKTURA CZYNNIKOWA}

W tabeli 3 zaprezentowano statystyki opisowe dla poszczególnych wersji Skali subiektywnej witalności. Wartości skośności i kurtozy zawierały się w przedziale od -1 do 1 .

Analiza głównych składowych wskazała jednoczynnikową strukturę narzędzia. Wartość własna pierwszego składnika wyniosła 4,29 i wyjaśniła 61,22\% ogółu wariancji. Jest to wynik porównywalny z tym uzyskanym przez Goldbecka i in. (2019; wartość własna: 4,23, wyjaśniona wariancja: 60,40\%). Następnie przeprowadzono konfirmacyjną analizę czynnikową. Wartości MLM $\chi^{2} / d f$, RMSEA oraz TLI dla M1 nie były na oczekiwanym poziomie. Można zauważyć, że wartość wskaźnika AIC z każdym następnym modelem malała, z czym związane jest lepsze dopasowanie (Akaike, 1987; tabela 4). W przypadku $\mathrm{MLM}^{2} / d f$ i RMSEA również Goldbeck i in. (2019) uzyskali nieakceptowalne wartości wskaźników. Kawabata i in. (2017) także wskazali wartość RMSEA bliską 0,1.

Tabela 3. Statystyka opisowa dla 7-, 6- i 5-pozycyjnej wersji Skali subiektywnej witalności w Polsce ( $=709)$

\begin{tabular}{cccccc}
\hline $\begin{array}{c}\text { Wersja } \\
\text { (liczba pozycji) }\end{array}$ & $\boldsymbol{M}$ & SD & Skośność & Kurtoza & a Cronbacha \\
\hline 7 & 29,89 & 10,18 & $-0,12$ & $-0,58$ & 0,89 \\
\hline 6 & 25,36 & 8,64 & $-0,04$ & $-0,56$ & 0,88 \\
\hline 5 & 21,29 & 6,16 & $-0,06$ & $-0,54$ & 0,85 \\
\hline
\end{tabular}

Następnie oceniono dopasowanie modelu $\mathrm{z}$ wykorzystaniem innego estymatora - diagonalnie ważonych kwadratów (DWLS). Uzyskane wyniki wskazały na dopasowanie modeli do danych, w tym 7-, 6- oraz 5-pozycyjnego (tabela 4). 
Tabela 4. Wyniki konfirmacyjnej analizy czynnikowej przeprowadzonej na 7-, 6- oraz 5-pozycyjnej polskiej wersji Skali subiektywnej witalności

\begin{tabular}{|c|c|c|c|c|c|c|c|c|c|}
\hline & Model & $x^{2}$ & $d f$ & CFI & TLI & RMSEA & RMSEA $90 \% \mathrm{Cl}$ & SRMR & AIC \\
\hline \multicolumn{10}{|c|}{ MLM } \\
\hline M1 & 7-pozycyjny & 180,923 & 14 & 0,911 & 0,866 & 0,155 & $0,135-0,176$ & 0,059 & 17806,046 \\
\hline M2 & $\begin{array}{l}\text { 6-pozycyjny } \\
\text { (pozycja } 2 \\
\text { wykluczona) }\end{array}$ & 80,480 & 9 & 0,948 & 0,914 & 0,130 & $0,105-0,157$ & 0,043 & 15166,252 \\
\hline M3 & $\begin{array}{l}\text { 5-pozycyjny } \\
\text { (pozycje } 2 \text { i } 5 \\
\text { wykluczone) }\end{array}$ & 66,803 & 5 & 0,936 & 0,905 & 0,163 & $0,129-0,198$ & 0,047 & 12900,476 \\
\hline \multicolumn{10}{|c|}{ DWLS } \\
\hline M1 & 7-pozycyjny & 56,351 & 14 & 0,989 & 0,984 & 0,065 & $0,048-0,084$ & 0,058 & \\
\hline M2 & $\begin{array}{l}\text { 6-pozycyjny } \\
\text { (pozycja } 2 \\
\text { wykluczona) }\end{array}$ & 21,302 & 9 & 0,996 & 0,993 & 0,044 & $0,020-0,068$ & 0,042 & \\
\hline M3 & $\begin{array}{l}\text { 5-pozycyjny } \\
\text { (pozycje } 2 \text { i } 5 \\
\text { wykluczone) }\end{array}$ & 17,669 & 5 & 0,992 & 0,985 & 0,060 & $0,031-0,091$ & 0,046 & \\
\hline
\end{tabular}

Adnotacja. M1 - Model 1; M2 - Model 2; M3 - Model 3; CFI - porównawczy indeks dopasowania; TLI indeks Tuckera-Lewisa; RMSEA - pierwiastek średniokwadratowego błędu aproksymacji; CI - 90-procentowy przedział ufności; SRMR - wystandaryzowany pierwiastek średniego kwadratu reszt; AIC - kryterium informacyjne Akaikego; MLM - metoda największej wiarygodności; DWLS - metoda diagonalnie ważonych kwadratów.

Znormalizowane ładunki czynnikowe wszystkich siedmiu pozycji były statystycznie istotne w zakresie od 0,64 (pozycja 6) do 0,84 (pozycja 4; tabela 5). Korelacje między pozycjami a średnią mieściły się w przedziale od $r=0,70$ do $r=0,84$, wskazując wystarczającą wspólną wariancję z wynikiem ogólnym. W przypadku wykorzystania estymatora DWLS ładunki czynnikowe i wariancja resztowa różniły się nieznacznie.

Wartość współczynnika alfa Cronbacha dla wszystkich skal wskazywała na wystarczającą zgodność wewnętrzną. Zależnie od wersji skali (5-, 6-, 7-pozycyjna) przyjmował wartości od 0,85 do 0,89 (tabela 3 ). 
Tabela 5. Charakterystyka psychometryczna pozycji na podstawie CFA (MLM) dla 7-elementowej wersji skali $(N=709)$

\begin{tabular}{cccccc}
\hline Pozycja & $M$ & SD & $\begin{array}{c}\text { Zależność } \\
\text { pozycja - skala }\end{array}$ & $\begin{array}{c}\text { tadunki } \\
\text { czynnikowe }\end{array}$ & $\begin{array}{c}\text { Wariancja } \\
\text { resztowa }\end{array}$ \\
\hline 1 & 4,63 & 1,91 & 0,80 & 0,77 & 0,40 \\
\hline 2 & 4,53 & 2,13 & 0,78 & 0,73 & 0,47 \\
\hline 3 & 3,94 & 1,95 & 0,76 & 0,69 & 0,52 \\
\hline 4 & 4,54 & 1,80 & 0,84 & 0,84 & 0,29 \\
\hline 5 & 4,07 & 1,83 & 0,83 & 0,81 & 0,34 \\
\hline 6 & 4,39 & 1,65 & 0,70 & 0,64 & 0,60 \\
\hline 7 & 3,79 & 1,76 & 0,75 & 0,68 & 0,54 \\
\hline
\end{tabular}

\section{BADANIA 3-6: TRAFNOŚĆ ZBIEŻNA I RÓŻNICOWA}

Przyjęto, że miarą trafności zewnętrznej Skali subiektywnej witalności będą zależności między subiektywną witalnością a wymiarami zmęczenia przewlekłego, symptomami somatycznymi, niepokojem, zaburzeniami funkcjonowania, symptomami depresji, poczuciem witalności, satysfakcją z życia oraz afektem pozytywnym i negatywnym, zaspokojeniem potrzeb psychologicznych ogólnie oraz w pracy w różnych próbach: studentów, pracowników, emerytów i sportowców. Wybór konstruktów był podyktowany, sugerowanymi w literaturze przedmiotu, wzajemnymi związkami między badanymi zmiennymi.

Zaobserwowano negatywne zależności przeciętne między subiektywną witalnością a wszystkimi wymiarami zmęczenia (subiektywnym odczuciem zmęczenia, pogorszeniem koncentracji uwagi, obniżeniem motywacji, zmniejszeniem aktywności) w grupie pracowników. Zanotowano negatywne zależności przeciętne między subiektywną witalnością a symptomami somatycznymi, niepokojem, zaburzeniami funkcjonowania oraz symptomami depresji w próbie emerytów. Negatywne zależności przeciętne zanotowano oprócz tego między subiektywną witalnością a afektem negatywnym we wszystkich badanych pod tym kątem grupach: pracowników, studentów, sportowców. 
Tabela 6. Korelacje subiektywnej witalności z wymiarami zmęczenia przewlekłego, negatywnym i pozytywnym afektem, satysfakcja z życia i witalnościa, liczba godzin poświęcanych na zajęcia rekreacyjne oraz zaspokojeniem potrzeb psychologicznych w ogóle oraz w odniesieniu do pracy (współczynniki korelacji $r$ Pearsona w grupach pracowników, $N=389$; studentów, $N=91$; sportowców, $N=244$; emerytów, $N=89$ )

\begin{tabular}{|c|c|c|c|c|}
\hline & Pracownicy & Emeryci & Studenci & Sportowcy \\
\hline & \multicolumn{4}{|c|}{ Trafność różnicowa } \\
\hline Subiektywne odczucie zmęczenia & $-0,40 * * *$ & & & \\
\hline Pogorszenie koncentracji uwagi & $-0,39 * * *$ & & & \\
\hline Obniżenie motywacji & $-0,39 * * *$ & & & \\
\hline Zmniejszenie aktywności & $-0,43^{* * *}$ & & & \\
\hline Negatywny afekt & $-0,44^{* * *}$ & & $-0,40^{* * *}$ & $-0,46^{* * *}$ \\
\hline Symptomy somatyczne & & $-0,42^{* * *}$ & & \\
\hline Niepokój & & $-0,35^{* * *}$ & & \\
\hline Zaburzenia funkcjonowania & & $-0,46^{* * *}$ & & \\
\hline \multirow[t]{2}{*}{ Symptomy depresji } & & $-0,36^{* * *}$ & & \\
\hline & \multicolumn{4}{|c|}{ Trafność zbieżna } \\
\hline Witalność & $0,65 * * *$ & $0,54^{* * *}$ & $0,69 * * *$ & $0,69 * * *$ \\
\hline Satysfakcja z życia & $0,49^{* * *}$ & & $0,51^{* * *}$ & $0,54^{* * *}$ \\
\hline \multirow[t]{2}{*}{ Pozytywny afekt } & $0,80^{* * *}$ & & $0,86^{* * *}$ & $0,81^{* * *}$ \\
\hline & \multicolumn{4}{|c|}{ Kryterium zewnętrzne } \\
\hline \multirow[t]{2}{*}{ Liczba godzin } & & & $0,19 * * *$ & $0,21 * * *$ \\
\hline & \multicolumn{4}{|c|}{ Potrzeby psychologiczne w pracy } \\
\hline Potrzeba autonomii w pracy & $0,26 * * *$ & & & \\
\hline Potrzeba kompetencji w pracy & $0,30^{* * *}$ & & & \\
\hline \multirow[t]{2}{*}{ Potrzeba relacji w pracy } & $0,14^{* *}$ & & & \\
\hline & \multicolumn{4}{|c|}{ Potrzeby psychologiczne - ogólnie } \\
\hline Potrzeba autonomii & & & $0,57^{* * *}$ & \\
\hline Potrzeba kompetencji & & & $0,69^{* * *}$ & \\
\hline Potrzeba relacji & & & $0,56^{* * *}$ & \\
\hline
\end{tabular}

*** $p<0,01 ; * * * 0,001$.

Analiza wykazała silne zależności subiektywnej witalności z witalnością - podskalą jakości życia (kwestionariusza SF-36) we wszystkich badanych grupach. Dodatkowo zanotowano przeciętną oraz pozytywne wysokie zależności między subiektywną witalnością a satysfakcją z życia (w zależności od próby). Uzyskano pozytywną bardzo wysoką zależność między afektem pozytywnym a subiektywną witalnością.

Liczba godzin spędzonych na aktywnościach rekreacyjnych była pozytywnie słabo związana $z$ subiektywną witalnością. Wszystkie trzy potrzeby psychologiczne oceniane w odniesieniu do pracy również były pozytywnie słabo związane $z$ subiektywną witalnością. Zależności między subiektywną witalnością a potrzebami psychologicznymi w rozumieniu ogólnym były natomiast pozytywne i wysokie. Szczegółowe wyniki zaprezentowano w tabeli 5 . 


\section{PODSTAWOWE POTRZEBY PSYCHOLOGICZNE}

Przeanalizowano wartość predykcyjną podstawowych potrzeb psychologicznych w pracy dla subiektywnej witalności. Regresja wieloraka wykazała, że potrzeby autonomii $(\beta=0,17$; $p<0,001)$ i kompetencji $(\beta=0,24 ; p<0,001)$ były istotnymi predyktorami subiektywnej witalności, $\mathrm{z}$ kolei potrzeba relacji $(\beta=-0,07 ; p>0,05)$ nie okazała się istotnym predyktorem. Model ten wyjaśnił $11 \%$ wariancji $(F[3,385]=15,12 ; p<0,001)$.

Postanowiono przeanalizować predykcję potrzeb psychologicznych w grupie studentów, nie zawężając ich odpowiedzi do obszaru pracy. Regresja wieloraka wykazała, że istotnym predyktorem subiektywnej witalności była wyłącznie potrzeba kompetencji $(\beta=0,51$; $p<0,001)$. Potrzeby autonomii $(\beta=0,11 ; p=0,36)$ i relacji $(\beta=0,18 ; p=0,10)$ okazały się predyktorami nieistotnymi. Model ten wyjaśniał ponad $51 \%$ wariancji $(F[3,87]=30,34$; $p<0,001)$. Zdecydowano się sprawdzić, czy po wprowadzeniu do modelu kolejno potrzeb autonomii i relacji zmienne te okażą się istotnymi predyktorami subiektywnej witalności. Potrzeba autonomii okazała się predyktorem istotnym $(\beta=0,57 ; p<0,001)$, wyjaśniając jednocześnie ponad $32 \%$ wariancji $(F[1,89]=42,23 ; p<0,001)$. Potrzeba relacji również okazała się istotnym predyktorem $(\beta=0,56 ; p<0,001)$. Model ten wyjaśniał ponad $31 \%$ wariancji $(F[1,89]=40,51 ; p<0,001)$. Model przetestowano także, gdy jako predyktor subiektywnej witalności wprowadzono wyłącznie potrzebę kompetencji. W tym przypadku wielkość współczynnika regresji była wyższa niż w przypadku pozostałych potrzeb psychologicznych $(\beta=0,69 ; p<0,001)$. Taki model wyjaśniał ponad $47 \%$ wariancji $(F[1,89]$ $=80,73 ; p<0,001)$. Należy jednak podkreślić, że najlepsze dopasowanie modelu uzyskano po wprowadzeniu jednocześnie trzech predyktorów. Analiza ta wykazała, że wśród potrzeb psychologicznych to potrzeba kompetencji stanowi najsilniejszy predyktor subiektywnej witalności.

Na podstawie uzyskanych wyników można stwierdzić, że zależność subiektywnej witalności od zaspokojenia potrzeb psychologicznych w pracy jest na niskim poziomie. Mimo że głównym zajęciem osób badanych była praca, to zaspokojenie potrzeb psychologicznych w jej obszarze w małym stopniu decydowało o poziomie subiektywnej witalności. Z kolei w przypadku predykcji potrzeb psychologicznych ogólnie wartość współczynnika regresji była znacznie wyższa.

\section{BADANIE 7: ANALIZA RÓŻNIC MIĘDZYGRUPOWYCH}

W trakcie prac nad adaptacją Skali subiektywnej witalności zbadano także osoby cierpiące na dyskopatię. Wyniki uzyskane $\mathrm{w}$ trakcie tego badania zestawiono $\mathrm{z}$ wynikami uzyskanymi $\mathrm{w}$ badaniu osób z grupy kontrolnej (grupy nie różniły się ze względu na wiek: $t=-1,96, p=$ $0,06)$. Osoby chore i zdrowe somatycznie różniły się istotnie wynikiem subiektywnej witalności. Siła efektu była na przeciętnym poziomie. Rezultaty porównania grup przedstawiono w tabeli 7.

Tabela 7.Zróżnicowanie wyników subiektywnej witalności w zależności od przynależności do grupy (osoby zdrowe vs osoby $z$ dyskopatią)

\begin{tabular}{|c|c|c|c|c|c|c|c|}
\hline & \multicolumn{2}{|c|}{ Osoby zdrowe } & \multicolumn{2}{|c|}{ Osoby chore } & \multirow{2}{*}{$t$} & \multirow{2}{*}{$p$} & \multirow{2}{*}{$d$ Cohena } \\
\hline & $M$ & SD & $M$ & SD & & & \\
\hline $\begin{array}{l}\text { Subiektywna } \\
\text { witalność }\end{array}$ & 19,30 & 5,35 & 16,32 & 7,33 & $-2,07$ & 0,04 & 0,464 \\
\hline
\end{tabular}




\section{DYSKUSJA}

Uzyskane wyniki pozwalają na częściowe potwierdzenie trafności czynnikowej Skali subiektywnej witalności i są porównywalne z wynikami zanotowanymi przez innych badaczy (Bostic i in., 2000; Goldbeck i in., 2019; Kawabata i in., 2017; Ryan, Frederick, 1997). Wartości wskaźników RMSEA i $\chi^{2} / d f$ odbiegały od oczekiwanych, co zanotowano również w przypadku wcześniejszych adaptacji skali. Należy jednak podkreślić, że wskaźnik RMSEA jest niestandaryzowaną wielkością efektu niedopasowania modelu (Maydeu-Olivares, 2017), a jego wartość ma różne znaczenie w zależności od struktury i wielkości modelu (Chen, Curran, Bollen, Kirby, Paxton, 2008; Savalei, 2012; Shi, Lee, Maydeu-Olivares, 2019). W celu przezwyciężenia problemów związanych z interpretacją wielkości niestandaryzowanych efektów niedopasowania zaleca się w ocenie modelu stosowanie wystandaryzowanych rozmiarów efektów niedopasowania modelu, takich jak SRMR (Maydeu-Olivares, 2017). W przypadku testowanych modeli wskaźnik ten przyjmował wartości pozwalające na zaakceptowanie modelu. W wyniku powtórnej analizy dopasowania modelu do danych z wykorzystaniem estymatora DWLS (z uwagi na współczynnik kurtozy wielowymiarowej) otrzymano wyniki pozwalające za zaakceptowanie modelu. Hipoteza o jednoczynnikowej strukturze skali (H1) została potwierdzona. Przeprowadzone analizy spójności wewnętrznej oraz mocy dyskryminacyjnej pozycji pozwoliły uznać polską wersję Skali subiektyrwnej witalności za rzetelną.

Zgodnie z przypuszczeniami wykazano negatywne zależności ze zmęczeniem przewlekłym, symptomami somatycznymi, niepokojem, zaburzeniami funkcjonowania oraz symptomami depresji i afektem negatywnym, co pozwala na potwierdzenie hipotezy drugiej (H2), oraz pozytywne korelacje subiektywnej witalności z afektem pozytywnym, satysfakcją z życia i witalnością, co z kolei pozwala na potwierdzenie hipotezy trzeciej (H3). Wyniki te są zgodne z wcześniejszymi ustaleniami (Dawes i in., 2014; Goldbeck i in., 2019; Gumz i in., 2015; Kenyon $i$ in., 2015; Rouse $i$ in., 2015; Uysal i in., 2014). Bardzo wysoka zależność między subiektywną witalnością a pozytywnym afektem mogłaby świadczyć o braku ortogonalności tych konstruktów. Jednak ich analiza teoretyczna wskazuje na to, że stanowią odrębne konstrukty. Podobieństwo stanowi to, że subiektywna witalność i afekt pozytywny rozpatrywane są w kategorii doświadczenia. Oba są związane zarówno z orientacją hedonistyczną, jak i eudajmonistyczną, jednak w różnym stopniu. Huta (2015) wykazała ponadto, że w porównaniu $\mathrm{z}$ afektem pozytywnym, zarówno na poziomie stanu, jak i cechy, witalność była silniej związana $z$ orientacją eudajmonistyczną oraz słabiej z orientacją hedonistyczną. Podkreślono różnicę na poziomie aktywacji między witalnością a afektem pozytywnym. Kolejna różnica dotyczy stopnia centralności danego pojęcia (Huta, 2015). Ryan i Deci (2006) rozpatrywali subiektywną witalność w ujęciu dobrostanu eudajmonistycznego, jako korelat dobrostanu psychicznego. $Z$ kolei pojęcie afektu pozytywnego jest niezbędne dla definicji hedonii, o czym świadczy zakres uwagi poświęcony mu zarówno w definicjach koncepcyjnych, jak i operacyjnych (core element, Huta, Waterman, 2014).

W odniesieniu do zależności zewnętrznych stwierdzono istotną pozytywną zależność między subiektywną witalnością a średnim czasem, jaki ludzie spędzają (w tygodniu) na zajęciach rekreacyjnych, co stanowi potwierdzenie hipotezy czwartej (H4). Uzyskany wynik jest spójny z doniesieniami Goldbecka i in. (2019).

Oceniono także, na ile potrzeby psychologiczne stanowią predyktory subiektywnej witalności. Skoncentrowano się zarówno na ogólnym zaspokojeniu potrzeb psychologicznych, jak i w odniesieniu do pracy. Model, w którym potrzeby psychologiczne w pracy stanowity predyktor subiektywnej witalności, wyjaśniał $11 \%$ wariancji, z kolei model, w którym predyktorem były ogólne potrzeby psychologiczne $-51 \%$. Odnosząc się do potrzeb psychologicznych w pracy, należy wskazać, że potrzeby autonomii i kompetencji były istotnymi 
predyktorami subiektywnej witalności (w przypadku kompetencji współczynnik regresji był wyższy). Wobec tego hipoteza piąta (H5), mówiąca, że satysfakcja z zaspokojenia potrzeb psychologicznych w pracy jest predyktorem subiektywnej witalności, została częściowo potwierdzona. Satysfakcja z zaspokojenia potrzeby relacji okazała się nieistotna. $Z$ kolei w przypadku ogólnych potrzeb psychologicznych istotnym predyktorem subiektywnej witalności była wyłącznie potrzeba kompetencji (przy wprowadzeniu wszystkich predyktorów jednocześnie). Przy wprowadzaniu potrzeb psychologicznych kolejno każda z potrzeb okazała się istotnym pozytywnym predyktorem. Można uznać, że hipoteza szósta (H6) została potwierdzona.

Uzasadnieniem tych wyników może być odniesienie do tego, jak potrzeby psychologiczne zaspokajane są w pracy i w czasie wolnym. Należy podkreślić, że badani, uzupełniając Skale podstawowych potrzeb psychologicznych w pracy, zawęzili swoje pole widzenia wyłącznie do pracy, w drugim przypadku odnosili się ogólnie do swojego życia. Praca ogranicza czas wolny, który opisuje się w kategoriach działań zapewniających doświadczenia wewnętrznie satysfakcjonujące (Iso-Ahola, 1980). W czasie wolnym ludzie częściej niż w pracy mogą wybierać działania i interakcje społeczne, które zapewniają wewnętrzną satysfakcję. Podkreśla się, że dla wielu pracowników wzorzec pracy/wypoczynku jest podobny do schematu dnia powszedniego/weekendu. Wiele osób twierdzi, że czuje się w pracy nieautonomicznie (Kasser, Cohn, Kanner, Ryan, 2007). Teoria autodeterminacji uwzględnia podstawową psychologiczną potrzebę bliskości i związków z innymi (Deci, Ryan, 2008). Potrzeba ta wykracza poza zwykłe przebywanie w otoczeniu innych ludzi. Na przykład w miejscu pracy osoby mogą przebywać wśród innych ludzi, ale nie czuć się blisko z nimi związani. Odnosząc się do potrzeby kompetencji, można odwołać się do badań Reisa i in. (2000). Podali oni, że poziom zaspokojenia potrzeby kompetencji był dla studentów stosunkowo stabilny przez cały tydzień, nie wykazując znaczącej różnicy między tygodniem (tygodniem pracy) a weekendem (czasem wolnym). Ryan, Bernstein i Brown (2010) zasugerowali, że zarówno w pracy, jak i w czasie wolnym dorośli mają możliwość doświadczenia poczucia kompetencji. W prezentowanym badaniu subiektywna witalność była rozpatrywana jako cecha, zatem jej ocena odnosi się do tego, jak osoba czuje się na ogół. Przypuszcza się, że wskazane aspekty stanowią o sile zależności między zaspokojeniem potrzeb psychologicznych ogólnie oraz w pracy a subiektywną witalnością. Może to prowadzić do wniosku, że zaspokajając potrzeby psychologiczne w określonym obszarze życia, na przykład w pracy, ludzie niekoniecznie będą mieli poczucie subiektywnej witalności, do tego jest bowiem niezbędne poczucie satysfakcji z zaspokojenia tych potrzeb ogólnie, w życiu.

Trafność teoretyczna została także potwierdzona istotnymi różnicami wyników subiektywnej witalności w grupach osób cierpiących na ból przewlekły oraz w grupie kontrolnej. Osoby z grupy kontrolnej osiągnęły istotnie wyższy wynik subiektywnej witalności niż osoby chore. Hipoteza siódma (H7) została potwierdzona.

Podsumowując: Skala subiektywnej witalności cechuje się dobrymi własnościami psychometrycznymi. Spełnia kryteria rzetelności i trafności teoretycznej, co daje możliwość wykorzystywania tego narzędzia w badaniach nad subiektywną witalnością w Polsce. Zaleca się stosowanie 5-pozycyjnej wersji skali.

Zaadaptowane narzędzie może być wykorzystane do diagnozy subiektywnej witalności w różnych populacjach, m.in.: studentów, pracowników, sportowców, osób zdrowych, jak i osób chorych. Dodatkowo może uposażyć naukowców chcących podejmować badania nad witalnością w gotowe narzędzie badawcze.

Prezentowane badanie ma ograniczenia. Rozkład liczebności kobiet w stosunku do mężczyzn nie jest proporcjonalny. Próbę stanowią w większości kobiety. Ankieta internetowa została rozpowszechniona za pomocą mediów społecznościowych. Stąd pomimo szerokiego przedziału wiekowego i dużego zróżnicowania wykształcenia i zawodu reprezentatywność próby jest ograniczona. Pomimo wskazanych ograniczeń zdecydowano się udostępnić 
polską wersję Skali subiektywnej witalności. Dane uzyskane w ramach badań zaprezentowanych $\mathrm{w}$ niniejszej publikacji oraz innych pracach walidacyjnych sugerują, że subiektywna witalność jest użytecznym konstruktem w badaniach na styku procesów psychologicznych i fizjologicznych. 


\section{ZAŁĄCZNIK 1 \\ SKALA SUBIEKTYWNEJ WITALNOŚCI \\ (RYAN, FREDERICK, 1997; ADAPTACJA: MUDŁO-GŁAGOLSKA, 2020)}

Proszę odnieść się do każdego z poniższych stwierdzeń, zaznaczając, w jakim stopniu dane stwierdzenie jest prawdziwe w Pani/Pana życiu.

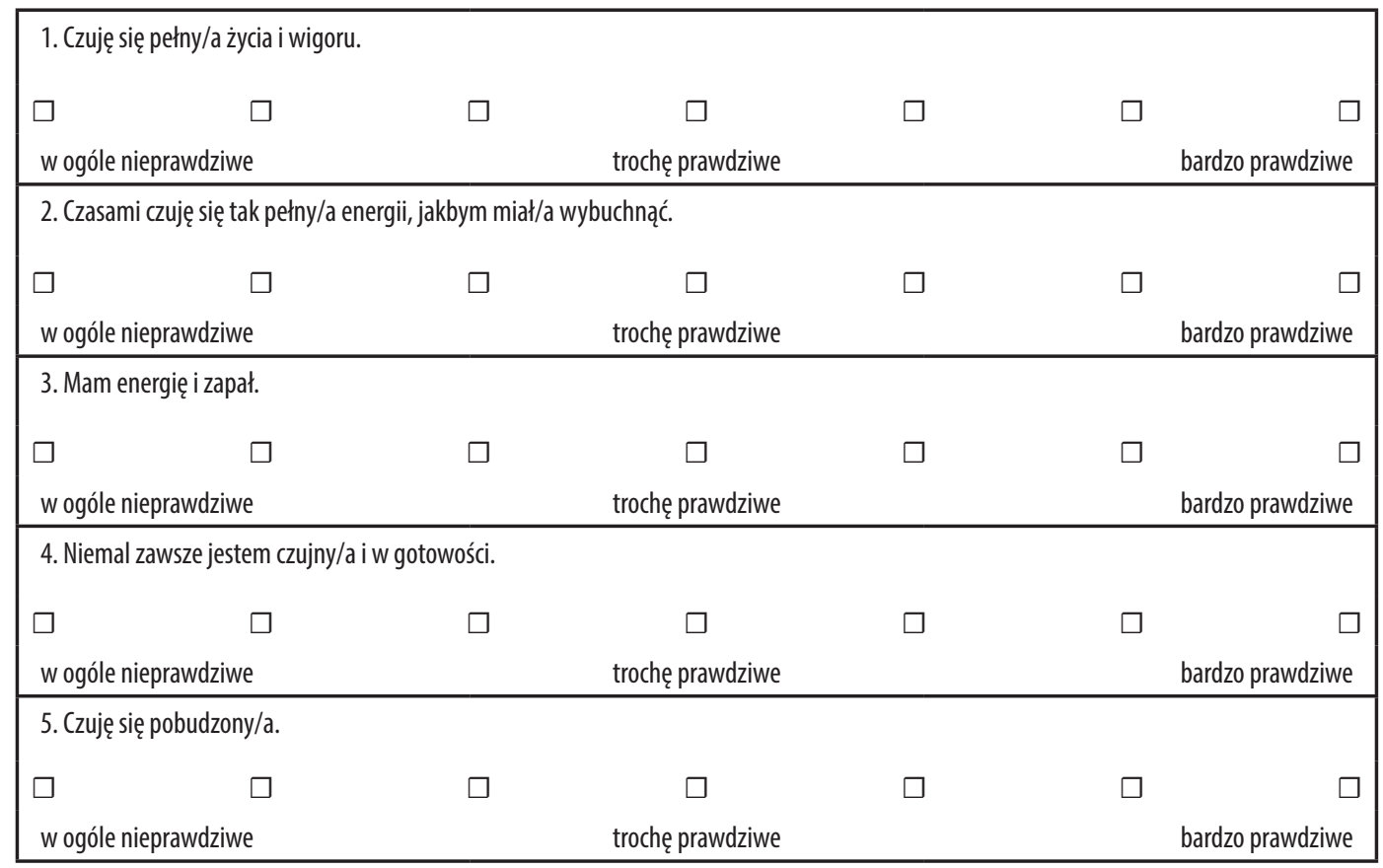




\section{BIBLIOGRAFIA}

Adie, J. W., Duda, J. L., Ntoumanis, N. (2012). Perceived coach-autonomy support, basic need satisfaction and the well-and ill-being of elite youth soccer players: A longitudinal investigation. Psychology of Sport and Exercise, 13(1), 51-59. D0l: 10.1016/j.psychsport.2011.07.008

Akaike, H. (1987). Factor analysis and AIC. Psychometrika, 52, 317-332. D0I: 10.1007/BF02294359

Arkes, H. R., Herren, L. T., Isen, A. M. (1988). The role of potential loss in the influence of affect on risk-taking behavior. Organizational Behavior and Human Decision Processes, 42(2), 181-193. D0I: 10.1016/0749-5978(88)90011-8

Benyamini, Y., Idler, E. L., Leventhal, H., Leventhal, E. A. (2000). Positive affect and function as influences on self-assessments of health: expanding our view beyond illness and disability. The Journals of Gerontology Series B: Psychological Sciences and Social Sciences, 55, 107-116. D0I: 10.1093/geronb/55.2.P107

Bertrams, A., Dyllick, T. H., Englert, C., Krispenz, A. (2020). German adaptation of the Subjective Vitality Scales (SVS-G). Open Psychology, 2, 57-75. D0I: 10.1515/ psych-2020-0005

Bostic, T. J., Rubio, D. M., Hood, M. (2000). A validation of the subjective vitality scale using structural equation modeling. Social Indicators Research, 52, 313-324. DOl: $10.1023 / \mathrm{A}: 1007136110218$

Brzozowski, P., Watson, D. B., Clark, L. A. (2010). Skala uczuć pozytywnych i negatywnych SUPIN. Polska adaptacja skali PANAS Davida Watsona i Lee Ann Clark. Podręcznik. Warszawa: Pracownia Testów Psychologicznych Polskiego Towarzystwa Psychologicznego.

Cohen, S., Alper, C. M., Doyle, W. J., Treanor, J. J., Turner, R. B. (2006). Positive emotional style predicts resistance to illness after experimental exposure to rhinovirus or influenza a virus. Psychosomatic Medicine, 68, 809-815. D0l: 10.1097/01.psy.0000245867.92364.3C

Chen, F., Curran, P. J., Bollen, K. A., Kirby, J., Paxton, P. (2008). An empirical evaluation of the use of fixed cutoff points in RMSEA test statistic in structural equation models. Sociological Methods \& Research, 36, 462-494. D0I: 10.1177/0049124108314720

Dawes, H., Collett, J., Meaney, A., Duda, J., Sackley, C., Wade, D., ... Izadi, H. (2014). Delayed recovery of leg fatigue symptoms following a maximal exercise session in people with multiple sclerosis. Neurorehabilitation and Neural Repair, 28, 139-148. D0I: 10.1177/1545968313503218

Deci, E. L., Ryan, R. M. (1985). The general causality orientations scale: Self-determination in personality. Journal of Research in Personality, 19, 109-134. D0I: 10.1016/0092-6566(85)90023-6

Deci, E. L., Ryan, R. M. (2000). The „What" and „Why" of goal pursuits: human needs and the self-determination of behavior. Psychological Inquiry, 11, 227-268. D0I: 10.1207/S15327965PLI1104_01

Deci, E. L., Ryan, R. M. (2008). Self-determination theory: a macrotheory of human motivation, development, and health. Canadian Psychology, 49, 182-185. D0I: $10.1037 / \mathrm{a} 0012801$

Gagné, M. (2003). The role of autonomy support and autonomy orientation in prosocial behavior engagement. Motivation and Emotion, 27, 199-223. D0l: 10.1023/A:1025007614869

Goldbeck, F., Hautzinger, M., Wolkenstein, L. (2019). Validation of the german version of the Subjective Vitality Scale - a cross-sectional study and a randomized controlled trial. Journal of Well-Being Assessment, 3, 17-37. D0I: 10.1007/s41543-019-00019-8

Gumz, A., Kästner, D., Raczka, K. A., Weigel, A., Osen, B., Rose, M., ... Karacic, M. (2015). Aggregating factors of the change process in the treatment of anorexia nervosa. Eating Behaviors, 19, 81-85. D0I: 10.1016/j.eatbeh.2015.06.002

Gunnell, K. E., Crocker, P. R., Mack, D. E., Wilson, P. M., Zumbo, B. D. (2014). Goal contents, motivation, psychological need satisfaction, well-being and physical activity: A test of self-determination theory over 6 months. Psychology of Sport and Exercise, 15, 19-29. D0l: 10.1016/j.psychsport.2013.08.005

Huta, V. (2015). The complementary roles of eudaimonia and hedonia and how they can be pursued in practice. W: S. Joseph (red.), Positive psychology in practice: Promoting human flourishing in work, health, education, and everyday life (s. 159-182). Hoboken, NJ: Wiley \& Sons. DOI: 10.1002/9781118996874.ch10

Huta, V., Waterman, A. S. (2014). Eudaimonia and its distinction from hedonia: developing a classification and terminology for understanding conceptual and operational definitions. Journal of Happiness Studies, 15, 1425-1456. D0I: 10.1007/s10902-013-9485-0

Iso-Ahola, S. E. (1980). The social psychology of leisure and recreation. Dubuque, lowa: William C Brown.

Juczyński, Z. (2001). Narzędzia pomiaru w promocji i psychologii zdrowia. Warszawa: Pracownia Testów Psychologicznych Polskiego Towarzystwa Psychologicznego.

Kasser, T., Cohn, S., Kanner, A. D., Ryan, R. M. (2007). Some costs of American corporate capitalism: a psychological exploration of value and goal conflicts. Psychological Inquiry, 18, 1-22. D0I: 10.1080/10478400701386579

Kawabata, M., Yamazaki, F., Guo, D. W., Chatzisarantis, N. L. D. (2017). Advancement of the Subjective Vitality Scale: examination of alternative measurement models for Japanese and Singaporeans. Scandinavian Journal of Medicine \& Science in Sports, 27, 1793-1800. D0I: 10.1111/sms.12760

Kenyon, M., Young, F., Mufti, G. J., Pagliuca, A., Lim, Z., Ream, E. (2015). Life coaching following haematopoietic stem cell transplantation: a mixed-method investigation of feasibility and acceptability. European Journal of Cancer Care, 24, 531-541. D0I: 10.1111/ecc.12297

Kline, R. B. (2005). Principles and practice of structural equation modeling (Methodology in the social sciences, wyd. 2). NY: Guilford Press.

Makowiec-Dąbrowska, T., Koszada-Włodarczyk, W. (2006). Przydatność kwestionariusza CIS20R do badania zmęczenia przewlekłego. Medycyna Pracy, $57,335-345$.

Makowska, Z., Merecz, D. (2001). Polska adaptacja kwestionariuszy ogólnego stanu zdrowia Davida Goldberga: GHQ-12 i GHQ-28. W: B. Dudek (red.), Ocena zdrowia psychicznego na podstawie badań kwestionariuszami Davida Goldberga. Podręcznik dla użytkowników kwestionariuszy GHQ-12 i GHQ-28 (s. 191-264). Łódź: IMP.

Martela, F., DeHaan, C. R., Ryan, R. M. (2016). On enhancing and diminishing energy through psychological means: Research on vitality and depletion from self-determination theory. W: E. R. Hirt, J. Clarkson, L. Jia (red.), Self-regulation and ego control (s. 67-85). Saint Louis: Academic Press.

Martela, F., Ryan, R. M. (2016). Prosocial behavior increases well-being and vitality even without contact with the beneficiary: Causal and behavioral evidence. Motivation and Emotion, 40, 351-357. D0I: 10.1007/s11031-016-9552-z

Maydeu-Olivares, A. (2017). Assessing the size of model misfit in structural equation models. Psychometrika, 82, 533-558. D0I: 10.1007/s11336-016-9552-7

Nix, G. A., Ryan, R. M., Manly, J. B., Deci, E. L. (1999). Revitalization through self-regulation: the effects of autonomous and controlled motivation on happiness and vitality. Journal of Experimental Social Psychology, 35(3), 266-284. D0l: 10.1006/jesp.1999.1382

Polk, D. E., Cohen, S., Doyle, W. J., Skoner, D. P., Kirschbaum, C. (2005). State and trait affect as predictors of salivary cortisol in healthy adults. Psychoneuroendocrinology, 30(3), 261-272. D0l: 10.1016/j.psyneuen.2004.08.004 
Reis, H. T., Sheldon, K. M., Gable, S. L., Roscoe, J., Ryan, R. M. (2000). Daily well-being: the role of autonomy, competence, and relatedness. Personality and Social Psychology Bulletin, 26, 419-435. D0l: 10.1177/0146167200266002

Rizzolatti, G., Sinigaglia, C. (2016). The mirror mechanism: a basic principle of brain function. Nature Reviews Neuroscience, 17, 757-765. D01: 10.1038/nrn.2016.135

Rouse, P. C., Veldhuijzen van Zanten, J. J. C. S., Ntoumanis, N., Metsios, G. S., Yu, C., Kitas, G. D., Duda, J. L. (2015). Measuring the positive psychological well-being of people with rheumatoid arthritis: a cross-sectional validation of the subjective vitality scale. Arthritis Research \& Therapy, 17(312), 1-7. D0I: 10.1186/ s13075-015-0827-7

Rozanski, A., Blumenthal, J. A., Davidson, K. W., Saab, P. G., Kubzansky, L. (2005). The epidemiology, pathophysiology, and management of psychosocial risk factors in cardiac practice: the emerging field of behavioral cardiology. Journal of the American College of Cardiology, 45, 637-651. D0l: 10.1016/j.jacc.2004.12.005

Ryan, R. M. (1995). Psychological needs and the facilitation of integrative processes. Journal of Personality, 63, 397-427. D0I: 10.1111/j.1467-6494.1995.tb00501.x Ryan, R. M., Bernstein, J. H., Brown, K. W. (2010). Weekends, work, and well-being: psychological need satisfactions and day of the week effects on mood, vitality, and physical symptoms. Journal of Social and Clinical Psychology, 29, 95-122. D01: 10.1521/jscp.2010.29.1.95

Ryan, R. M., Deci, E. L. (2001). On happiness and human potentials: a review of research on hedonic and eudaimonic well-being. Annual Review of Psychology, 52(1), 141-166. D0I: 10.1146/annurev.psych.52.1.141

Ryan, R. M., Deci, E. L. (2006). Self-regulation and the problem of human autonomy: does psychology need choice, self-determination, and will? Journal of Personality, 74, 1557-1586. D0I: 10.1111/j.1467-6494.2006.00420.x

Ryan, R. M., Deci, E. L. (2008). From ego depletion to vitality: theory and findings concerning the facilitation of energy available to the self. Social and Personality Psychology Compass, 2, 702-717. D0I: 10.1111/j.1751-9004.2008.00098.x

Ryan, R. M., Deci, E. L. (2017). Self-determination theory: basic psychological needs in motivation, development, and wellness. New York, NY: Guilford Press. D0I: 10.7202/1041847ar

Ryan, R. M., Frederick, C. (1997). On energy, personality, and health: subjective vitality as a dynamic reflection of well-being. Journal of Personality, 65, 529-565. D0I: 10.1111/j.1467-6494.1997.tb00326.x

Salama-Younes, M. (2011). Positive mental health, subjective vitality and satisfaction with life for French physical education students. World Journal of Sport Sciences, 4, 90-97.

Savalei, V. (2012). The relationship between root mean square error of approximation and model misspecification in confirmatory factor analysis models. Educational and Psychological Measurement, 72, 910-932. D0I: 10.1177/0013164412452564

Selye, H. (1956). The stress of life. NY: McGraw-Hill.

Sheldon, K. M., Kasser, T. (1995). Coherence and congruence: two aspects of personality integration. Journal of Personality and Social Psychology, 68, 531-543. D0I: 10.1037//0022-3514.68.3.531

Sheldon, K. M., Ryan, R., Reis, H. T. (1996). What makes for a good day? Competence and autonomy in the day and in the person. Personality and Social Psychology Bulletin, 22, 1270-1279. D0I: 10.1177/01461672962212007

Shi, D., Lee, T., Maydeu-Olivares, A. (2019). Understanding the model size effect on SEM fit indices. Educational and Psychological Measurement, 79, 310-334. D01: $10.1177 / 0013164418783530$

Souza, L. A. S. de, Torres, A. R. R., Barbosa,G. A., Lima, T. J. S. de, Souza, L. E. C. de. (2015). Bem-estar subjetivo e burnout em cadetes militares: 0 papel mediador da autoeficácia. Psicologia: Reflexão e Crítica, 28, 744-752. D01: 10.1590/1678-7153.201528412

Tylka, J., Piotrowicz, R. (2009). Kwestionariusz oceny jakości życia SF-36 - wersja polska (Quality of life SF-36 questionnaire - the Polish version). Kardiologia Polska (Polish Heart Journal), 67, 1166-1169.

Uchnast, Z. (2007). Skala Podstawowych Potrzeb Psychologicznych, E. L. Deci, R. M. Ryan. Tekst niepublikowany. Lublin: KUL.

Uysal, R., Satici, S. A., Satici, B., Akin, A. (2014). Subjective vitality as mediator and moderator of the relationship between life satisfaction and subjective happiness. Educational Sciences: Theory and Practice, 14(2), 489-497. D0l: 10.12738/estp.2014.2.1828

Wang, W. C., Chen, H. F., Jin, K. Y. (2015). Item response theory models for wording effects in mixed-format scales. Educational and Psychological Measurement, 75 , 157-178. DOI: 10.1177/0013164414528209 